\title{
Analysis of Similarities Between the European Union \\ sciendo \\ Countries in Terms of Sustainable Energy \\ and Climate Development
}

doi:10.2478/mape-2021-0008

Date of submission to the Editor: 04/2021

Date of acceptance by the Editor: 05/2021

MAPE 2021, volume 4, issue 1, pp. 86-96

\section{Magdalena Tutak}

ORCID ID: 0000-0003-4781-8697

Silesian University of Technology, Poland

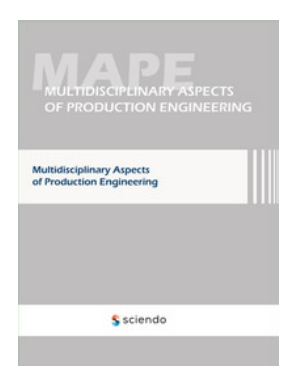

\section{INTRODUCTION}

Sustainable development is a complex, multidimensional concept, the meaning of which may vary depending on the context and the perspective of a participant in this process (Markovska and Taseska; Tutak et al., 2020; Tutak et al., 2021). Both energy and climate issues are an important component of this process (Brodny and Tutak, 2020, Brodny et al., 2020; Brodny and Tutak, 2019; Im and Kim, 2020) They have become one of the fundamental goals of international policy, as evidenced by their inclusion in Agenda 2030 (United Nations, 2015) among a total of 17 Sustainable Development Goals, the achievement of which is planned for 2030. In terms of sustainable energy and climate development, the agenda includes goal no. 7 - "Affordable and Clean Energy" and no. 13 "Climate Action".

The implementation of Agenda 2030 goals is taking place in all member states of the United Nations, including the EU countries. This is because the very concept of sustainable development is a fundamental and overarching objective for the European Community, which was included in the Lisbon Treaty (2007). Therefore, both the goals of Agenda 2030 and the EU are convergent in terms of sustainable development, including energy and climate development. This involves concern for the environment, sustainable consumption and production as well as poverty eradication. The issues of climate protection and green energy development play a key role in the sustainable development of the EU. In order to develop a low-carbon economy and increase energy security of the EU countries, a number of strategies have been developed and their specific objectives have been defined. One of the most recent strategies in this area is the European climate strategy called the European Green Deal (2019), which aims to achieve climate neutrality and a "zero-emission" economy by 2050. A key role in this process will be played by the shift from conventional energy sources to renewable, or so-called green, sources. 
Activities related to climate protection and energy transition have been undertaken in the EU for years. Despite this, the EU countries are characterized by considerable diversity in this field. Therefore, it seems reasonable to conduct research on the similarity of the EU countries in terms of sustainable energy and climate development. This will make it possible to fill the research gap in the field of energy and climate condition in the group of these countries. Such analysis will consider not only climatic and energy factors, but also social and economic aspects that can lead to the elimination of energy poverty in society, among other effects.

Therefore, the aim of the research, the results of which are presented in this paper, was to analyze similarities between the EU countries in terms of sustainable energy and climate development. The analysis was carried out for all EU countries, based on 14 indicators characterizing energy and climate sustainability, in energy, climate, social and economic dimensions. Kohonen's artificial neural networks were used for analysis. The research was conducted for data from the period between 2009-2018. The results showed significant differences between the EU countries in the studied period (10 years).

This paper showed a new and original approach to the presented subject due to the wide scope of analysis, the inclusion of many factors from different areas, as well as the research tool used for analysis.

\section{METHODOLOGY OF RESEARCH}

In order to conduct a comparative analysis of similarities between the EU countries in terms of sustainable energy and climate development, data from the Eurostat database were used. The time period included in the research was between 2009-2018. The characteristics and values of indicators adopted for analysis are presented in Table 1.

Table 1 Sustainable energy and climate development indicators for EU-27 countries

\begin{tabular}{|c|c|c|c|c|}
\hline Dimension & Indicator & Description & Symbol & $\begin{array}{c}\text { Stimulant/ } \\
\text { Destimulant }\end{array}$ \\
\hline \multirow{4}{*}{$\begin{array}{c}\text { Primary energy } \\
\text { consumption, tonnes } \\
\text { of oil equivalent } \\
\text { per capita }\end{array}$} & $\begin{array}{c}\text { The indicator measures } \\
\text { the total energy needs } \\
\text { of a country excluding } \\
\text { all non-energy use } \\
\text { of energy carriers }\end{array}$ & X1 & D \\
\cline { 2 - 5 } & $\begin{array}{c}\text { Final energy } \\
\text { consumption, tonnes } \\
\text { of oil equivalent } \\
\text { per capita }\end{array}$ & $\begin{array}{c}\text { The indicator measures } \\
\text { the energy end-use in } \\
\text { a country excluding all } \\
\text { non-energy use } \\
\text { of energy carriers }\end{array}$ & X2 & D \\
\cline { 2 - 5 } & $\begin{array}{c}\text { Final energy } \\
\text { fonsumption in } \\
\text { hous much electricity } \\
\text { and heat every citizen } \\
\text { kg of oil equivalent } \\
\text { consumes at home } \\
\text { excluding energy used } \\
\text { for transportation. }\end{array}$ & $\mathrm{X} 3$ & $\mathrm{D}$ \\
\hline
\end{tabular}




\begin{tabular}{|c|c|c|c|c|}
\hline & $\begin{array}{l}\text { Energy productivity, } \\
\text { Euro per kilogram } \\
\text { of oil equivalent }\end{array}$ & $\begin{array}{l}\text { The indicator refers to } \\
\text { the energy consumed } \\
\text { by the production unit } \\
\text { of GDP }\end{array}$ & $\mathrm{X} 4$ & $S$ \\
\hline & $\begin{array}{c}\text { Share of renewable } \\
\text { energy in gross final } \\
\text { energy consumption, } \\
\%\end{array}$ & $\begin{array}{l}\text { This indicator measures } \\
\text { how extensive the use } \\
\text { of renewable energy is }\end{array}$ & $\times 5$ & $\mathrm{~S}$ \\
\hline & $\begin{array}{c}\text { Energy import } \\
\text { dependency by } \\
\text { products, \% of imports } \\
\text { in total gross available } \\
\text { energy } \\
\end{array}$ & $\begin{array}{c}\text { The indicator shows } \\
\text { the share of total energy } \\
\text { needs of a country met } \\
\text { by imports from other } \\
\text { countries. }\end{array}$ & $\mathrm{X} 6$ & $\mathrm{D}$ \\
\hline $\begin{array}{l}\overline{\bar{\pi}} \\
\bar{\delta}\end{array}$ & $\begin{array}{l}\text { Population unable to } \\
\text { keep home adequately } \\
\text { warm by poverty } \\
\text { status, } \% \text { of population }\end{array}$ & $\begin{array}{l}\text { The indicator measures } \\
\text { the share of population } \\
\text { who are unable to keep } \\
\text { home adequately warm. }\end{array}$ & $\mathrm{X} 7$ & $\mathrm{D}$ \\
\hline \multirow{4}{*}{ 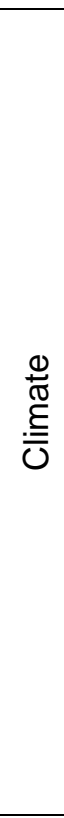 } & $\begin{array}{l}\text { Greenhouse gas } \\
\text { emissions, tonnes } \\
\text { per capita }\end{array}$ & $\begin{array}{l}\text { The indicator measures } \\
\text { total national emissions } \\
\text { of the so called 'Kyoto } \\
\text { basket' of greenhouse } \\
\text { gases }\end{array}$ & $\mathrm{x} 8$ & $D$ \\
\hline & $\begin{array}{c}\text { GHG Intensity } \\
\text { of Energy - kg CO} 2 \\
\text { eq./toe }\end{array}$ & $\begin{array}{l}\text { The indicator is } \\
\text { calculated as the ratio } \\
\text { between energy-related } \\
\text { GHG emissions } \\
\text { and gross inland } \\
\text { consumption of energy }\end{array}$ & X9 & $\mathrm{D}$ \\
\hline & $\begin{array}{l}\text { Total GHG - GDP } \\
\text { Intensity - ton } \mathrm{CO}_{2} \\
\text { eq./M€'15 }\end{array}$ & $\begin{array}{l}\text {-This indicator } \\
\text { measures ratio between } \\
\text { GHG emissions } \\
\text { and GDP }\end{array}$ & $\mathrm{X} 10$ & $D$ \\
\hline & $\begin{array}{c}\text { Average } \mathrm{CO}_{2} \\
\text { emissions per km from } \\
\text { new passenger cars, } \mathrm{g} \\
\mathrm{CO}_{2} \text { per km }\end{array}$ & $\begin{array}{l}\text { The indicator is defined } \\
\text { as the average carbon } \\
\text { dioxide emissions per } \\
\mathrm{km} \text { by new passenger } \\
\text { cars in a given year. }\end{array}$ & $\mathrm{X} 11$ & $\mathrm{D}$ \\
\hline \multirow{3}{*}{$\begin{array}{l}\vec{\xi} \\
\stackrel{0}{0} \\
\text { 己 }\end{array}$} & GDP per capita & $\begin{array}{l}\text { This indicator is } \\
\text { calculated as the ratio } \\
\text { of real GDP to the } \\
\text { average population } \\
\text { of a specific year }\end{array}$ & $\mathrm{X} 12$ & $\mathrm{~S}$ \\
\hline & $\begin{array}{l}\text { Electricity prices by } \\
\text { type of user (medium } \\
\text { size house), euro per } \\
\text { kilowatt-hour }\end{array}$ & $\begin{array}{l}\text { This indicator presents } \\
\text { electricity prices } \\
\text { charged to final } \\
\text { Consumers }\end{array}$ & $\mathrm{X} 13$ & $\mathrm{D}$ \\
\hline & $\begin{array}{l}\text { Electricity prices by } \\
\text { type of user (medium } \\
\text { size consumers), } \\
\text { euro per kilowatt-hour }\end{array}$ & $\begin{array}{l}\text { This indicator presents } \\
\text { electricity prices } \\
\text { charged to final medium } \\
\text { size consumers }\end{array}$ & $\mathrm{X} 14$ & $D$ \\
\hline
\end{tabular}

Source: Own elaboration based on Eurostat

Kohonen's artificial neural networks were used to determine similarities between the EU countries in terms of sustainable energy and climate development. They are a type of self-learning and self-organizing artificial neural networks. Also, they have several important characteristics that justify their application in data clustering processes. These networks can map complex multidimensional input- 
output relationships in a low-dimensional space while preserving a topological structure of the original data. They also provide flexibility in grouping data with similar properties (Kohonen, 1990).

Kohonen's neural networks are built with two layers of neurons: an input layer and an output layer (called the competitive layer or Kohonen's layer). The output layer consists of radial neurons, which form a topological map after the network is trained (Muczyński, 2009). All neurons in the input layer are connected to neurons in the output layer by different weights. The initial values of the weights are generated using either random or linear assignment methods. The nodes of neurons in the output layer, which have the same dimension as the input design variables, form a two-dimensional mesh (topological map). In the learning process, the Euclidean distances between the design vector and the weighted vector neuron nodes in the competitive layer are taken as indicators to determine the best match. Once the best match is obtained, the weight value of this match, as well as of neighboring neurons, will be updated to approach the design vector. This training process is repeated until the design vector and the nodes of the neurons in the competitive layer are fully matched (Zhou et al., 2017).

The algorithm used in the Kohonen's method is as follows (Brodny and Tutak, 2020b):

- To determine the size of the topological map (1):

$$
k \cong \sqrt{\frac{n}{2}}
$$

where:

$k$ - number of neurons (clusters),

$n$ - number of cases (countries).

- To trigger the initial weight vectors.

- To select the learning case (observation).

- To calculate the value of the decision function for all neurons and select the winning neuron.

- To determine neurons adjacent to the winning neuron based on the value of the neighborhood function.

- To adjust the weights of neighboring neurons using the learning rate (adaptation).

- To modify the learning rate and neighborhood size.

- To implement step 2 again if the conditions for completing the learning process of the network have not been met.

A Euclidean measure is used to calculate the distance between input data $(x)$ and neuron weights $(w)$ :

$$
d(x, w)=\sqrt{\sum_{i=1}^{k}\left(x_{i j}-w_{i j}\right)^{2}}
$$




\section{RESULTS AND DISCUSSION}

Based on 14 indicators of sustainable energy and climate development adopted for the study, an analysis was performed to determine groups of EU countries similar in terms of this development for a 10-year period between 2009-2018. The first analysis involved grouping of the EU countries based on data from 2009. In the first stage, cluster compositions were determined for the 2009 data, which are presented in Table 2 together with the value of the activation function.

Table 2 Elements of clusters and the value of the activation function for 2009

\begin{tabular}{|c|c|c|c|}
\hline $\begin{array}{c}\text { Cluster } 1 \text { and value } \\
\text { of activation function }\end{array}$ & $\begin{array}{c}\text { Cluster } 2 \text { and value } \\
\text { of activation function }\end{array}$ & $\begin{array}{c}\text { Cluster } \mathbf{3} \text { and value } \\
\text { of activation function }\end{array}$ & $\begin{array}{c}\text { Cluster } \mathbf{4} \text { and value } \\
\text { of activation function }\end{array}$ \\
\hline Belgium (0.47) & Slovenia (0.64) & Spain (0.53) & Czech Republic (0.43) \\
\hline Denmark (1.02) & Estonia (0.68) & Croatia (0.73) & Greece (0.46) \\
\hline Germany (0.44) & Latvia (0.67) & Hungary (0.51) & Cyprus (0.70) \\
\hline Ireland (0.69) & Lithuania (0.50) & Malta (0.64) & Poland (0.37) \\
\hline France (0.75) & Romania (0.40) & Portugal (0.74) & Bulgaria (0.90) \\
\hline Italy (0.72) & & Slovakia (0.35) & \\
\hline Luxembourg (1.29) & & & \\
\hline Netherlands (0.38) & & & \\
\hline Austria (0.68) & & & \\
\hline Finland (0.88) & & & \\
\hline Sweden (1.34) & & & \\
\hline
\end{tabular}

Countries located inside one cluster are the most similar to one another in terms of energy and climate sustainability, but at the same time, significantly different from countries located in other clusters. In turn, countries in the same cluster show the greatest similarity to one another when located in the central part of the cluster. The further a country is from the center of the cluster, the less similar it is to countries in the center. At the same time, assigning such a country to another cluster would be unjustified because of the lack of similarity to countries in that cluster.

The distribution of countries in the created clusters is shown on the topological map in Figure 1.

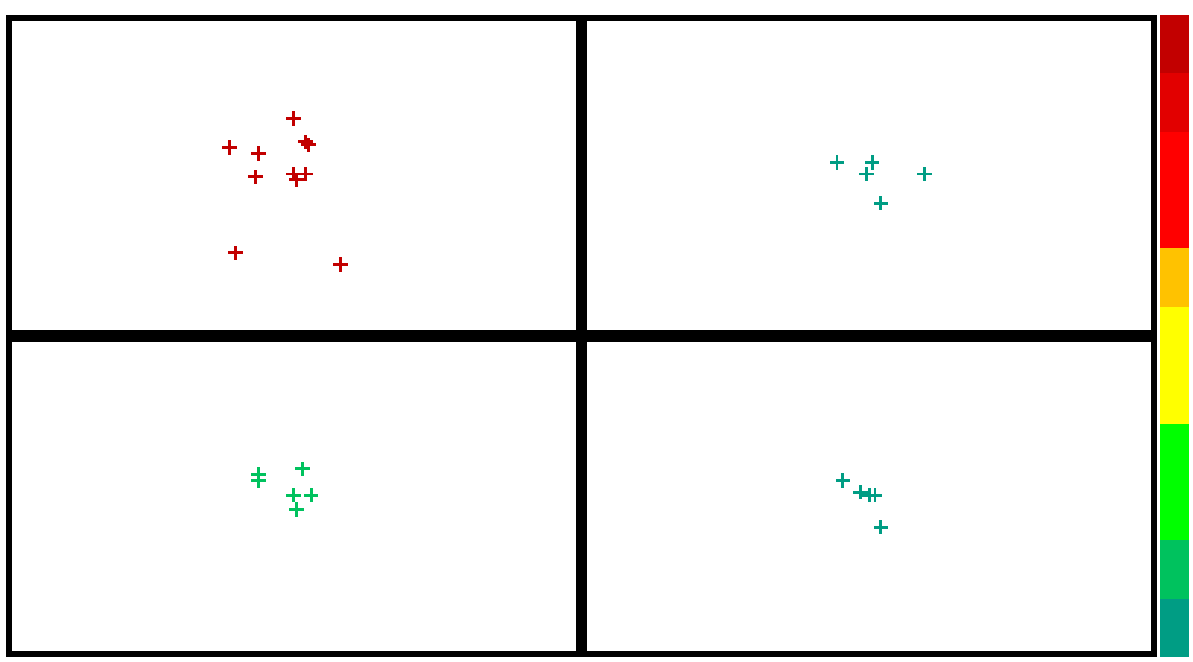

Fig. 1 Distribution of the EU countries in clusters (neurons) on' the topological map in 2009 
The analysis of the distribution of the EU countries on the topological map showed that the greatest internal differences were reported for countries in cluster 1 (e.g., Belgium, Sweden, Finland, Germany), and the greatest similarities for countries in cluster 3 (e.g., Spain, Croatia, Hungary) and 4 (e.g., Czech Republic, Poland, Cyprus, Bulgaria).

The results showed that countries with the highest average level of sustainable energy and climate development in 2009 were in cluster 1 , and countries with the lowest average level of development - in cluster 4. Cluster 1 included Sweden, Denmark, Austria, and France. These countries should be regarded as leaders in sustainable energy and climate development in the EU. The high position of Sweden, Denmark and Austria results from the fact that their transformation in the energy sector and the gradual transition to renewable energy began as early as the 1970 s, which also translated into their climate policy. France, on the other hand, is a country that bases its energy system mainly on nuclear energy, which makes this highly industrialized country combine the goal of economic growth and reduction of greenhouse gas emissions.

Among the countries with the lowest level of sustainable energy and climate development in 2009 was Bulgaria, which is the least wealthy country in the European Community. This country uses energy based on coal and nuclear sources. The total environmental footprint in the form of greenhouse gas emissions in Bulgaria is one of the highest among the EU countries. Bulgaria is also a country with a very high energy poverty rate (more than $64 \%$ of the population in 2009).

The basic statistics of the analysis carried out for each cluster are presented in Table 3. In this way specific features of each cluster, formed by a different number of EU countries, were determined.

Table 3 Results of statistical analysis on energy and climate sustainability for each cluster (2009)

\begin{tabular}{|c|c|c|c|c|c|c|c|}
\hline Cluster & Indicator & Mean & Median & $\begin{array}{c}\text { Standard } \\
\text { deviation }\end{array}$ & $\begin{array}{c}\text { Coefficient of } \\
\text { variation }\end{array}$ & Skewness & Kurtosis \\
\hline \multirow{6}{*}{} & $\mathrm{X} 1$ & 4.44 & 3.82 & 1.67 & 37.61 & 1.95 & 4.16 \\
\cline { 2 - 8 } & $\mathrm{X} 2$ & 3.45 & 3.13 & 1.70 & 49.35 & 2.56 & 7.18 \\
\cline { 2 - 8 } & $\mathrm{X} 3$ & 776.64 & 778.00 & 137.54 & 17.71 & 0.83 & 0.43 \\
\cline { 2 - 8 } & $\mathrm{X} 4$ & 8.15 & 7.59 & 2.05 & 25.21 & 0.51 & -0.08 \\
\cline { 2 - 8 } & $\mathrm{X} 5$ & 16.61 & 12.22 & 14.36 & 86.48 & 1.14 & 0.55 \\
\cline { 2 - 8 } & $\mathrm{X} 6$ & 56.81 & 61.10 & 32.26 & 56.78 & -1.29 & 2.46 \\
\cline { 2 - 8 } & $\mathrm{X} 7$ & 3.64 & 2.90 & 3.03 & 83.20 & 1.34 & 2.14 \\
\cline { 2 - 8 } & $\mathrm{X} 8$ & 12.19 & 11.90 & 5.08 & 41.69 & 2.06 & 5.68 \\
\cline { 2 - 8 } & $\mathrm{X} 9$ & 1973.03 & 2075.87 & 546.13 & 27.68 & -0.48 & -0.80 \\
\cline { 2 - 8 } & $\mathrm{X} 10$ & 293.92 & 303.43 & 58.36 & 19.85 & -1.31 & 1.86 \\
\cline { 2 - 8 } & $\mathrm{X} 11$ & 147.32 & 146.90 & 9.41 & 6.38 & 0.26 & -0.53 \\
\cline { 2 - 8 } & $\mathrm{X} 12$ & 37508.18 & 34040.00 & 12886.49 & 34.36 & 2.69 & 8.06 \\
\cline { 2 - 8 } & $\mathrm{X} 13$ & 0.19 & 0.19 & 0.04 & 22.22 & -0.01 & 0.47 \\
\cline { 2 - 8 } & $\mathrm{X} 14$ & 0.09 & 0.10 & 0.02 & 23.99 & -0.27 & -1.64 \\
\hline \multirow{4}{*}{2} & $\mathrm{X} 1$ & 2.39 & 2.27 & 0.72 & 30.24 & 1.12 & 2.06 \\
\cline { 2 - 8 } & $\mathrm{X} 2$ & 1.54 & 1.47 & 0.44 & 28.63 & 0.29 & -2.48 \\
\cline { 2 - 8 } & $\mathrm{X} 3$ & 523.60 & 496.00 & 196.05 & 37.44 & -0.02 & -2.34 \\
\cline { 2 - 8 } & $\mathrm{X} 4$ & 3.15 & 3.10 & 0.72 & 22.74 & -0.49 & -0.71 \\
\hline
\end{tabular}




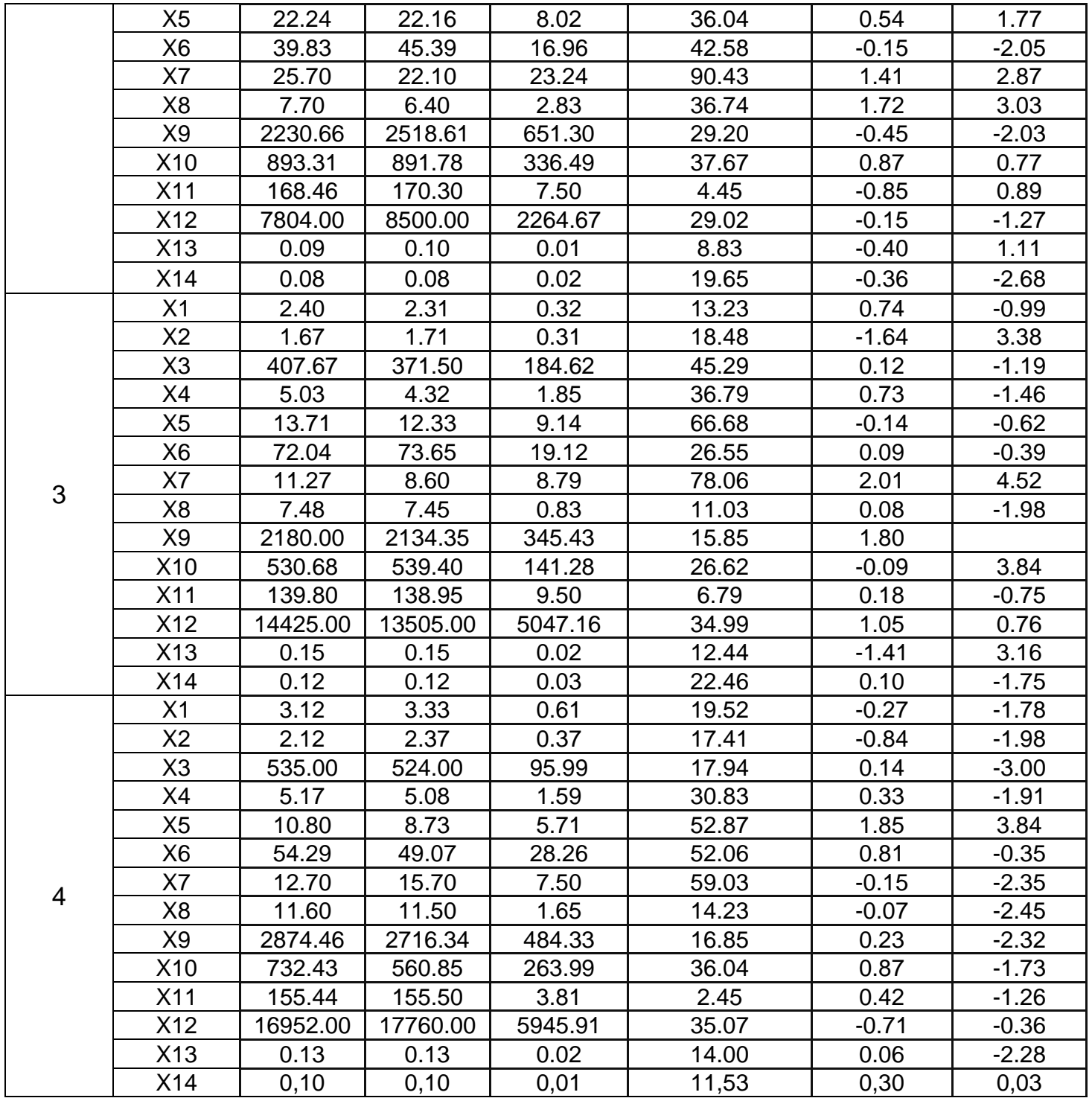

The next stage of the analysis involved grouping the EU countries by similarity in terms of their energy and climate sustainability based on the 2018 data. The created clusters are presented in Table 4, and the distribution of countries on the topological map for each cluster is shown in Figure 2.

Table 4 Elements of clusters and the value of the activation function for 2018

\begin{tabular}{|c|c|c|c|}
\hline $\begin{array}{c}\text { Cluster 1 and value } \\
\text { of activation function }\end{array}$ & $\begin{array}{c}\text { Cluster } 2 \text { and value } \\
\text { of activation function }\end{array}$ & $\begin{array}{c}\text { Cluster } 3 \text { and value } \\
\text { of activation function }\end{array}$ & $\begin{array}{c}\text { Cluster } 4 \text { and value } \\
\text { of activation function }\end{array}$ \\
\hline Belgium (0.62) & Slovenia (0.61) & Greece (0.69) & Czech Republic (0.29) \\
\hline Denmark (0.82) & Croatia (0.54) & Spain (0.42) & Estonia (0.75) \\
\hline Germany (0.68) & Latvia (0.57) & Italy (0.47) & Poland (0.56) \\
\hline Ireland (1.42) & Lithuania (0.48) & Cyprus (0.74) & Bulgaria (0.95) \\
\hline France (0.74) & Hungary (0.47) & Malta (0.87) & \\
\hline Luxembourg (3.23) & Romania (0.67) & Portugal (0.57) & \\
\hline Netherlands (0.78) & Slovakia (0.64) & & \\
\hline Austria (0.46) & & & \\
\hline Finland (1.51) & & & \\
\hline Sweden (0.99) & & & \\
\hline
\end{tabular}




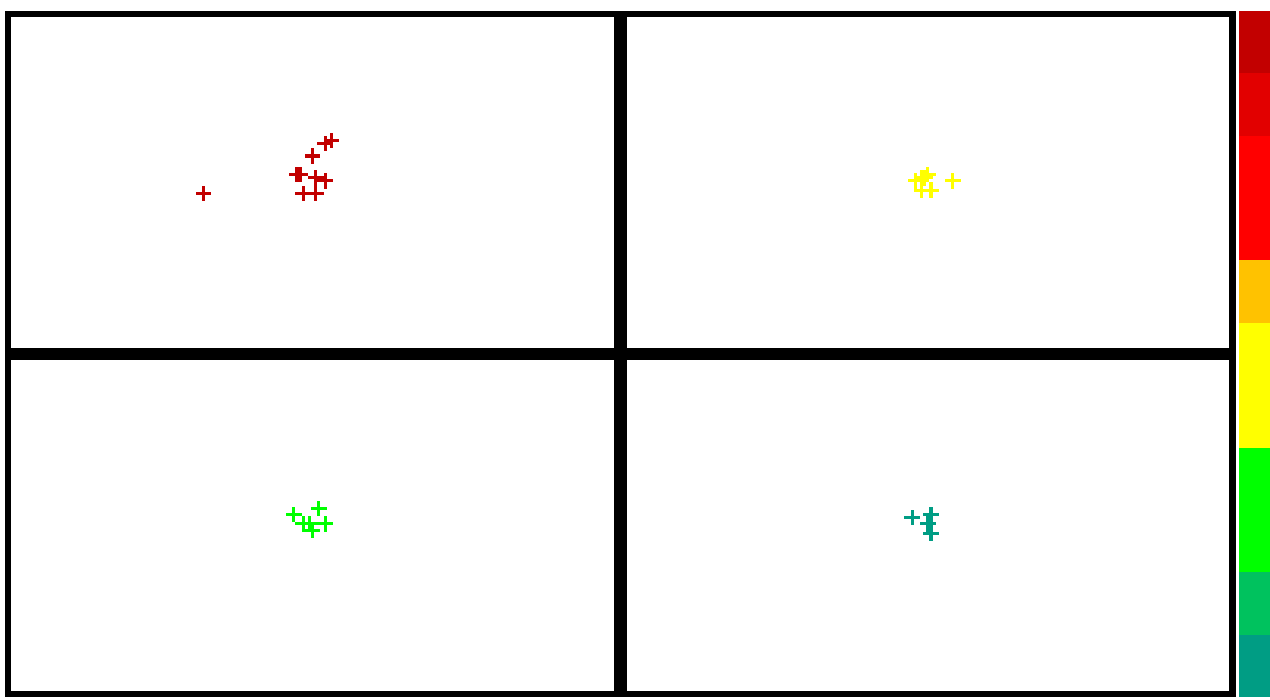

Fig. 2 Distribution of the EU countries in clusters (neurons) on the topological map in 2018

Table 5 summarizes the basic statistics on the conducted analysis for individual clusters.

Table 5 Results of statistical analysis on energy and climate sustainability for each cluster (2018)

\begin{tabular}{|c|c|c|c|c|c|c|c|}
\hline Cluster & Indicator & Mean & Median & $\begin{array}{l}\text { Standard } \\
\text { deviation }\end{array}$ & $\begin{array}{l}\text { Coefficient } \\
\text { of variation }\end{array}$ & Skewness & Kurtosis \\
\hline \multirow{14}{*}{1} & $\mathrm{X} 1$ & 4.26 & 3.68 & 1.38 & 32.53 & 1.56 & 1.86 \\
\hline & $\mathrm{X} 2$ & 3.41 & 3.03 & 1.48 & 43.38 & 2.17 & 4.91 \\
\hline & X3 & 721.00 & 721.50 & 142.93 & 19.82 & 1.01 & 1.44 \\
\hline & $\mathrm{X} 4$ & 10.13 & 9.01 & 3.97 & 39.20 & 1.33 & 1.57 \\
\hline & $\mathrm{X} 5$ & 23.48 & 16.56 & 16.51 & 70.33 & 0.80 & -0.66 \\
\hline & $\mathrm{X6}$ & 57.67 & 61.63 & 22.20 & 38.50 & 0.04 & -0.41 \\
\hline & $\mathrm{X7}$ & 3.02 & 2.50 & 1.35 & 44.80 & 0.78 & -1.07 \\
\hline & $\mathrm{X} 8$ & 10.77 & 10.70 & 4.04 & 37.55 & 1.38 & 3.30 \\
\hline & $\mathrm{X9}$ & 1693.13 & 1726.64 & 538.72 & 31.82 & -0.36 & -0.40 \\
\hline & $\mathrm{X} 10$ & 221.12 & 218.64 & 53.11 & 24.02 & -0.79 & 0.51 \\
\hline & $\mathrm{X} 11$ & 118.23 & 118.00 & 8.48 & 7.17 & 0.18 & -0.91 \\
\hline & $\mathrm{X} 12$ & 51110.00 & 44260.00 & 18864.37 & 36.91 & 2.14 & 4.75 \\
\hline & $\mathrm{X} 13$ & 0.22 & 0.19 & 0.06 & 26.88 & 0.69 & -1.39 \\
\hline & $\mathrm{X} 14$ & 0.08 & 0.08 & 0.02 & 23.32 & 2.14 & 5.72 \\
\hline \multirow{14}{*}{2} & $\mathrm{X} 1$ & 2.34 & 2.43 & 0.41 & 17.40 & -0.48 & 0.03 \\
\hline & $\mathrm{X} 2$ & 1.77 & 1.90 & 0.35 & 19.95 & -0.66 & -0.96 \\
\hline & X3 & 489.00 & 533.00 & 123.16 & 25.19 & -0.27 & -1.84 \\
\hline & $\mathrm{X} 4$ & 4.60 & 4.84 & 1.02 & 22.26 & -1.99 & 4.86 \\
\hline & $\times 5$ & 23.10 & 23.88 & 9.64 & 41.74 & 0.62 & 0.60 \\
\hline & $\mathrm{X} 6$ & 50.52 & 52.70 & 16.95 & 33.56 & -0.24 & -0.51 \\
\hline & $\mathrm{X7}$ & 13.90 & 7.70 & 11.76 & 84.59 & 1.25 & -0.37 \\
\hline & $\mathrm{X} 8$ & 6.94 & 6.60 & 0.96 & 13.76 & 0.48 & -1.79 \\
\hline & X9 & 1844.86 & 1719.46 & 289.19 & 15.68 & 0.71 & -1.05 \\
\hline & $\mathrm{X} 10$ & 605.31 & 499.28 & 249.08 & 41.15 & 2.43 & 6.05 \\
\hline & $\mathrm{X} 11$ & 125.54 & 127.70 & 5.08 & 4.05 & -1.58 & 1.67 \\
\hline & $\mathrm{X} 12$ & 13272.86 & 13910.00 & 3125.57 & 23.55 & -0.80 & -0.37 \\
\hline & $\mathrm{X} 13$ & 0.13 & 0.13 & 0.02 & 17.43 & 0.10 & -1.47 \\
\hline & $\mathrm{X} 14$ & 0.09 & 0.09 & 0.00 & 4.09 & 0.56 & -0.50 \\
\hline \multirow{4}{*}{3} & $\mathrm{X} 1$ & 2.34 & 2.32 & 0.44 & 18.81 & -0.14 & -0.36 \\
\hline & $\mathrm{X} 2$ & 1.74 & 1.75 & 0.29 & 16.83 & 0.06 & -1.27 \\
\hline & X3 & 347.00 & 343.00 & 113.33 & 32.66 & 0.49 & 1.08 \\
\hline & $\mathrm{X} 4$ & 7.33 & 7.43 & 2.20 & 29.93 & -1.00 & 2.40 \\
\hline
\end{tabular}




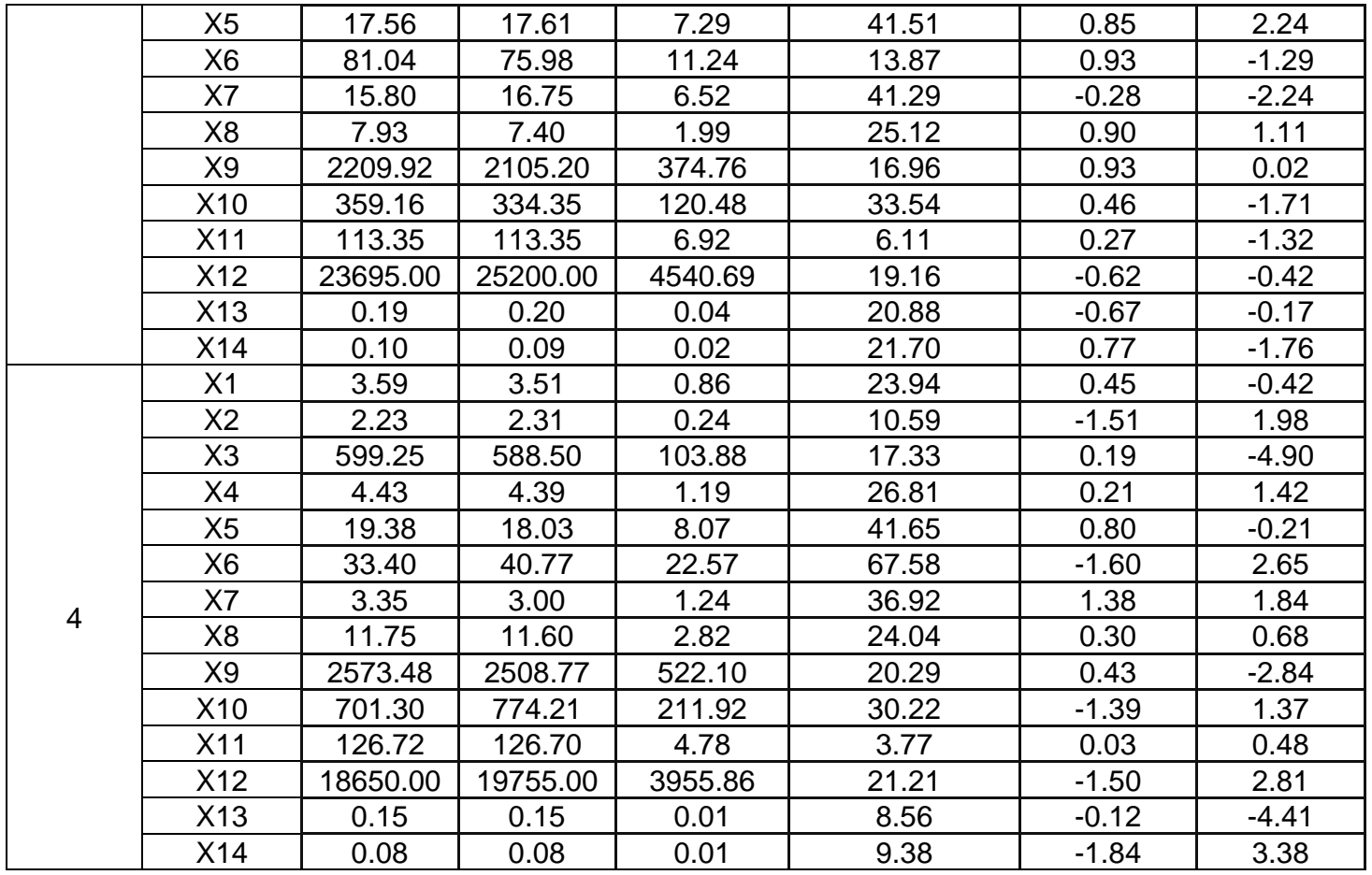

Source: Own elaboration

The results showed that countries with the highest average level of sustainable energy and climate development in 2018 were found in cluster 1, and countries with the lowest average level of this development - in cluster 4. It was found that cluster compositions changed insignificantly versus 2009. Italy, which in 2009 was in cluster 1, in 2018, was the most similar to countries from cluster 3 . Croatia and Slovakia were found to be in cluster 2 (in 2009, they were in cluster 3 ). Greece, on the other hand, was in cluster 4 in 2009, and in 2018, it was in cluster 3. Estonia, which showed similarity to countries in cluster 2 in 2009, was reported to have the greatest similarity to countries in cluster 4 in 2018.

Changes that occurred in the composition of individual clusters indicate the progress or its lack in the pursuit of sustainable energy and climate development of individual countries. In general, only Croatia, Slovakia and Greece slightly improved their energy and climate development over the 10-year period (apart from the leading countries in cluster 1, which maintained a high level of development the whole time).

\section{CONCLUSION}

The paper presents the results of similarity analysis of the EU countries in terms of sustainable energy and climate development for 2009-2018. The analysis was conducted using 14 indicators of energy and climate development, focusing on the priority areas of the EU in terms of the latest concept of the European Green Deal and Goals 7 and 13 of the 2030 Agenda for Sustainable Development. The analysis was performed in energy, environmental, economic, and social dimensions, using Kohonen's artificial neural networks (the so-called self-organizing maps). 
The created clusters of similar countries showed their high differentiation. At the same time, this division made it possible to assess changes in the studied area over a period of 10 years and indicate countries to which special assistance should be addressed, aimed both at substantive and financial support in energy and climate transformation. Such measures should be directed at undertaking more intensive actions in the scope of energy sector modernization and reduction of greenhouse gas emissions. Countries that require special attention in this area include Bulgaria, Poland, Estonia, and the Czech Republic. The situation of these countries in the studied 10-year period did not improve in relation to other EU countries.

The method applied and the results obtained provide great opportunities for a broader analysis in the field of sustainable climate and energy development of the EU countries, also in terms of the impact of examined areas on this development.

\section{REFERENCES}

A European Green Deal (2019) [online]. Available at: https://ec.europa.eu/info/strategy/priorities-2019-2024/european-green-deal_en (accessed on 11 January 2021).

Brodny, J. and Tutak, M. (2019). Analysis of the diversity in emissions of selected gaseous and particulate pollutants in the European Union countries. Journal of Environmental Management, 231, pp. 582-595.

Brodny, J. and Tutak, M. (2020a). Analyzing Similarities between the European Union Countries in Terms of the Structure and Volume of Energy Production from Renewable Energy Sources. Energies, 13, 913.

Brodny J. and Tutak M. (2020b). The Use of Artificial Neural Networks to Analyze Greenhouse Gas and Air Pollutant Emissions from the Mining and Quarrying Sector in the European Union. Energies, 13, 1925.

Brodny J., Tutak M., Saki S.A. (2020). Forecasting the Structure of Energy Production from Renewable Energy Sources and Biofuels in Poland. Energies 13, 2539.

Eurostat [online]. Available at: https://ec.europa.eu/eurostat/web/main/data/statistics-az/abc (accessed on 15 May 2021).

Kohonen T. (1990). The self-organizing map. Proc. IEEE, 78, pp. 1464-1480.

Im H. and Kim Y. (2020). The Electrification of Cooking Methods in Korea - Impact on Energy Use and Greenhouse Gas Emissions. Energies, 13, 680.

Markovska N. and Taseska V. (2009). Pop-Jordanov, J. SWOT analyses of the national energy sector for sustainable energy development. Energy, 34, pp. 752-756.

Muczyński A. (2009). Grupowanie nieruchomości wspólnot mieszkaniowych z wykorzystaniem sieci Kohonena. Acta Sci. Pol., Administratio Locorum, 8(4), pp. 5-15.

Treaty of Lisbon Amending the Treaty on European Union and the Treaty Establishing the European Community (2007) [online]. Available at: https://eurlex.europa.eu/legal-content/EN/TXT/?uri=CELEX:12007L/TXT (accessed on 11 January 2021).

Tutak M., Brodny J., Siwiec D., Ulewicz R., Bindzár P. (2020). Studying the Level of Sustainable Energy Development of the European Union Countries and Their Similarity Based on the Economic and Demographic Potential. Energies 13, 6643.

Tutak M., Brodny J., Bindzár, P. (2021) Assessing the Level of Energy and Climate Sustainability in the European Union Countries in the Context of the European Green Deal Strategy and Agenda 2030. Energies 14, 1767. 
United Nations. General Assembly Transforming Our World: The 2030 Agenda for Sustainable Development. New York. (2015) [online]. Available at: https://sdgs.un.org/2030agenda (accessed on 15 March 2021).

Zhou Q., Wang Y., Jiang P., Shao X., Choi S.K., Hu J., Cao L., Meng X. (2017). An active learning radial basis function modeling method based on self-organization maps for simulation-based design problems. Knowl.-Based Syst., 131, pp. 10-27.

\begin{abstract}
Energy and climate issues are an essential part of the sustainable development process of the EU countries. They are also one of the primary objectives of international policy, as evidenced by their inclusion in Agenda 2030, adopted by the UN in 2015 among the Sustainable Development Goals. The implementation of these goals is also taking place in the EU countries. Although climate protection and energy transition activities have been undertaken in the EU for years, individual countries significantly vary in this regard. The aim of the research, the results of which are presented in this paper, was to analyze similarities between the EU countries in terms of sustainable energy and climate development. The analysis was conducted for all EU countries, based on 14 indicators characterizing energy and climate sustainability, in energy, climate, social and economic dimensions. Kohonen's artificial neural networks were used for analysis. The research was conducted for data from the period between 2009-2018. The results showed that in the studied period (10 years), significant differences were found between the EU countries. A high level of energy and climate development was reported for Sweden, Denmark, Austria and France, among other states, and a low level for e.g., the Czech Republic, Poland and Bulgaria.
\end{abstract}

Keywords: sustainable energy and climate development, similarity analysis, EU countries, artificial neural networks 